\title{
Study of heavy metal concentration and partitioning in the Estrela River: implications for the pollution in Guanabara Bay - SE Brazil
}

\author{
CARLOS M.A. RANGEL ${ }^{1}$, JOSÉ A. BAPTISTA NETO ${ }^{1}$, ESTEFAN M. FONSECA ${ }^{1}$, \\ JOHN MCALISTER ${ }^{2}$ and BERNARD J. SMITH ${ }^{2}$ \\ ${ }^{1}$ Departamento de Geologia, Universidade Federal Fluminense Av. Litorânea s/n, Gragoatá, 24210-340 Niterói, RJ, Brasil \\ ${ }^{2}$ Scholl of Geography-Queen's University Belfast Belfast, Northern Ireland, BT7 1NN, United Kingdom \\ Manuscript received on November 24, 2009; accepted for publication on October 5, 2010
}

\begin{abstract}
In this study, the geochemical analysis of ten sediment samples collected along the fluvial system of the Estrela River, which flows into the northern portion of Guanabara Bay, shows the presence of anthropogenic impacts in this area. Concentrations of $\mathrm{Fe}, \mathrm{Mn}, \mathrm{Zn}, \mathrm{Cu}, \mathrm{Pb}, \mathrm{Cr}$ and $\mathrm{Ni}$ obtained were slightly higher, when compared with values found in natural environments. The particle size and organic matter content in most of the analyzed stations showed features not conducive to the accumulation of pollutants due to the low organic matter content and the strong presence of sand fraction. There was also the fractionation of heavy metals in sediments and it was found the prominence of residual and reducible phase, besides the significant occurrence of organic fractions in some analyzed stations. These factors, thus, highlight the potential risks of contamination, where the metals associated with the organic phase can become bioavailable in processes of dissolution, provided by physico-chemical changes that can occur in this aquatic environment.
\end{abstract}

Key words: Estrela River, Guanabara Bay, heavy metal, fractionation.

\section{INTRODUCTION}

The emissions of pollutants to the environment are strongly associated with different types of human activities that discard wastewater of domestic and industrial origin. These pollutants are scavenged by the sediments or mobilized in solutions associated with biological and chemical mechanisms, thereby contaminating the environment and biota and causing serious impacts to the receiving ecosystems (Akcay et al. 2003, Gismera et al. 2003, Pagnanelli et al 2004). Guanabara Bay has a long history of contaminant input that has resulted in high levels of trace metals in this estuarine system. This process of pollution is linked mainly to the fact that this bay is located in an industrialized and urbanized area that receives large amounts of domestic and industrial

Correspondence to: Carlos Marclei Arruda Rangel

E-mail: marclei@igeo.uff.br effluents (Baptista Neto et al. 2000a, Machado et al. 2001, Carreira et al. 2002). The introduction of pollutants in rivers and estuaries, located mainly in urban and industrial centers has caused an intense process of contamination in these aquatic environments. Nowadays, Guanabara Bay shows high levels of pollutants, such as heavy metals (Baptista Neto et al. 2006, Faria and Sanchez 2001, Kjerve et al. 1997, Perin et al. 1997), and the main sources of pollution to this bay are the rivers systems. Due to the high capacity of complexing pollutants, the sediments are considered good indicators of the water quality and record the effects caused by the pollution derived from anthropogenic emissions. For this reason, the sediment is widely used in the environment studies. The aquatic sediments are composed mainly by a mixture of materials from different origins: natural and anthropogenic (Gismera et 
al. 2003, Pagnanelli et al. 2004). In an impacted environment by heavy metals, it is necessary to assess the chemical forms and potential bioavailability and toxicity of heavy metals in order to understand their mobility in the biogeochemical processes, identify, monitor and control the sources of the pollutants and characterize the potential risks induced (Campbell and Tessier 1989, Warren and Haack 2001). The aim of the present study was, therefore, to investigate the impact of heavy metals and their effects on the Estrela River sediments as a result of human settlement and development in the catchments, as well as their possible impact in Guanabara Bay. In order to achieve it, the sediments were analyzed by sequential extraction methods to identify the chemical phases of the heavy metals, and the sediments were also analyzed for particle size, organic matter and physical-chemical parameters.

\section{ENVIRONMENTAL SETTING}

Guanabara Bay is located in southwest Brazil and is considered one of the largest bays in this country. This has an area of approximately $380 \mathrm{~km}^{2}$ and a water surface of $328 \mathrm{~km}^{2}$. Its drainage basin measures about $4.000 \mathrm{~km}^{2}$, with 45 rivers and channels (Kjerve et al. 1997). The drainage basin consists of 45 rivers and channels, though only 6 of these represent $85 \%$ of the total discharge of freshwater bay. All the rivers in this basin have high slopes in their degree courses, and this characteristic is attenuated when close to the perimeter of the bay, where they have low slopes and meander (Amador 1997). The Estrela River basin is located in the northern portion of Guanabara Bay and has an area of $450 \mathrm{~km}^{2}$ flowing in the north of this ecosystem and contributing with the water and sediment's intake (Fig. 1). The climatic characteristics of the Estrela River basin resemble those of Rio de Janeiro State. It has a tropical humid climate, with temperatures that reach more than $25^{\circ} \mathrm{C}$ in the lower portions and heat indexes around $13^{\circ} \mathrm{C}$ in higher points of this area (FEEMA 1990). The main tributaries of the Estrela River are: the Saracuruna, Inhomirim and Imbariê rivers. The Saracuruna River is the major tributary of the Estrela River, draining a heterogeneous region that consists of predominantly urban areas and is characterized by problems of infrastructure such as lack of sanitation. In the eastern margin, the main river receives the Imbariê River that is also located in a densely populated area without basic sanitation and, for this reason, is considered the main recipient of effluents produced in this region. The Inhomirim River is located almost entirely in a predominantly rural area, except for some small urban centers that also contribute to the emission of discards in this environment (Noronha 1998). The Estrela River basin is located almost entirely between Duque de Caxias and Magé cities, where inhabits a large contingent of population and where the most important economic activies are developed due to the fact that this is mainly an urban and industrial area (Noronha 1998). The high degree of urbanization occurs mainly in the lower portion of this basin, where the landfills are impacted by the growing human occupation. It is estimated that about 600.000 people live in the Estrela/Inhomirim basin, and some companies established in this region are responsible for potentially polluting activities and also contribute to the environmental degradation in Guanabara Bay (FEEMA 1998).

\section{MATERIALS AND METHODS}

\section{SAMPle Collection}

The field work was carried out in May 18, 2005, during the morning, in the period of spring tide, and the sediment sampling was under the influence of the flood tidal flow along the stations in the Estrela River. In this stage, ten superficial samples along the Estrela River basin were collected, and the stations 8, 9 and 10 were colleted in the main river. The collection was carried out with the aid of a boat with a van Veen grab sampler. The other sites were collected directly in the river without a boat, in the main tributaries of the Estrela River: the Saracuruna, Inhomirim and Imbariê rivers (Fig. 2). The samples were positioned with the use of a GPS. The collected sediments were kept in a temperature of about $4^{\circ} \mathrm{C}$ before being analyzed in the laboratory. The physical-chemistry data were obtained through the analysis of the sediments in situ with the respective instruments: portable $\mathrm{pH}$ meter (model Q$400 \mathrm{H}$ ), condutivimeter (Q-405P) and oximeter (Q-758 $\mathrm{P})$. The values of temperatures were obtained during the collection through a simple mercury thermometer that was inserted in the samples. 


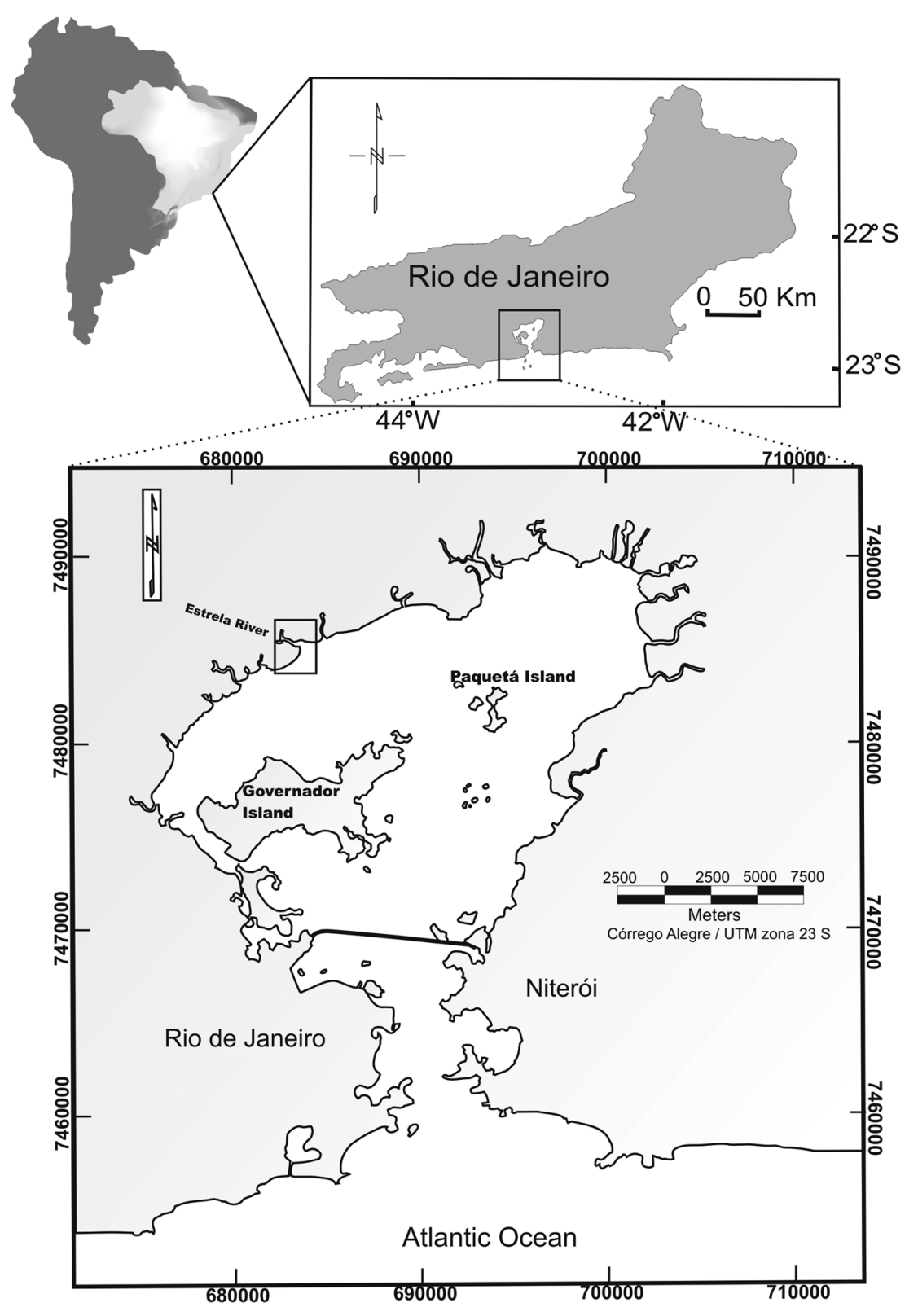

Fig. 1 - Location map of the studied area.

\section{THE LABORATORY ANALYSES}

\section{PARTICLE SIZE}

The grain size analysis of sediment samples was carried out using standard sieve techniques (for $>62 \mu \mathrm{m}$, Wentworth scale) and a pipette $(<62 \mu \mathrm{m})$ after the destruction of organic matter with $\mathrm{H}_{2} \mathrm{O}_{2}$. In the analysis of total organic matter, the calcination method was used and the sediment samples were conditioned in porcelain crucible, which had its weight previously determined.
After filled with the samples, the crucible was weighted again and taken to a muffle at $450^{\circ} \mathrm{C}$ for 24 hours. After this, the weights from the crucible were taken again, so the organic matter content in the samples could be obtained by the difference among masses.

\section{Heavy Metals}

The speciation procedure employed both shaking and heating techniques. Samples $(0.5 \mathrm{~g})$ were weighed into acid-washed polypropylene centrifuge tubes, and 


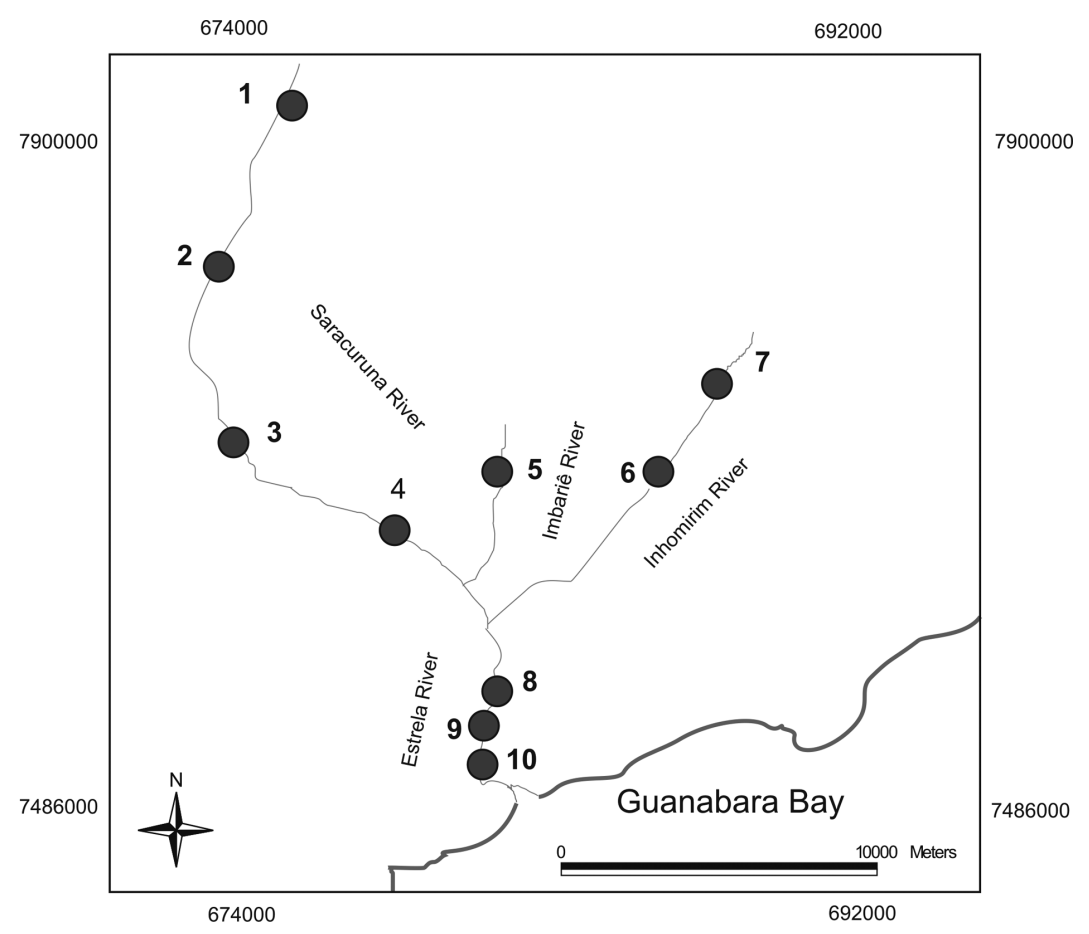

Fig. 2 - Location map of the studied area with the location of the superficial samples.

blanks were prepared taking each extractant without the sample through all the preparation procedures prior to analyses. Analytical grad chemicals were used and all solutions were prepared in deionized water. Watersoluble ions were extracted using a technique described by Buurman et al. (1996), which was modified by extracting $0.5 \mathrm{~g}$ of sample in $2.5 \mathrm{~cm}^{3}$ of $0.2-\mu \mathrm{m}-\mathrm{mem}-$ brane-filtered deionized water. Sample extracts were also membrane-filtered $(0.2 \mu \mathrm{m})$ prior to IC analyses. The total dissolution of the residual phase was carried out by microwave digesting $0,1 \mathrm{~g}$ in $3 \mathrm{ml}$ of $\mathrm{HNO}_{3}$, $1,5 \mathrm{ml}$ of $\mathrm{HF}$ and $1,5 \mathrm{ml}$ of $\mathrm{HCl}$ for $20 \mathrm{~min}$ at $1000 \mathrm{~W}$ of power and maximum pressure, followed by $15 \mathrm{~min}$ of cooling. The excess fluoride was complexed by adding $6 \mathrm{ml}$ of saturated $\mathrm{H}_{3} \mathrm{BO}_{3}$ solution and digesting and cooling for $15 \mathrm{~min}$, respectively. A Certified Reference Material (CRM) sediment sample from the Institute of Geophysical and Geochemical Exploration (IGGE), PR China, was analyzed under the same conditions.

\section{RESULTS AND DISCUSSION}

\section{PhysicAl-Chemical PARAMETERS}

The values of the physical-chemical parameters were obtained through the analysis of the sediments in situ, which were sufficiently coherent with the physical characteristics of the study area. The fluvial sediments showed values of $\mathrm{pH}$ ranging between 5.67 and 7.18, being well characteristic values of places that possess significant levels of organic matter. It is assumed that the values of $\mathrm{pH}$ in stations 8,9 and 10 were above 7 , for the input of water from the bay, due to the fact that the sampling was carried out in a period of flood tide. On the other hand, the salinity measured in the Estrela River shows values of $0.1 \%$ in these three stations mentioned above. According to Esteves (1998), salty waters that have salinity less than $0.5 \%$ can be classified as freshwater. Despite of this analysis being carried out during high tide, in this period the intensity of the fluvial flow was probably higher if it is compared with the tide current that reaches this area. It can be deduced that, at the moment of the analysis, a small amplitude of tides coexisted with the flow of the river that was more intense. When the seawater is denser than the river water, it flows under the fluvial waters constituting, therefore, a saline wedge.

The dissolved fractions of oxygen ranged between 0.04 and $9.3 \mathrm{mg} / \mathrm{l}$. From the analysis of these data, it is evident that the presence of oxygen in the superficial 

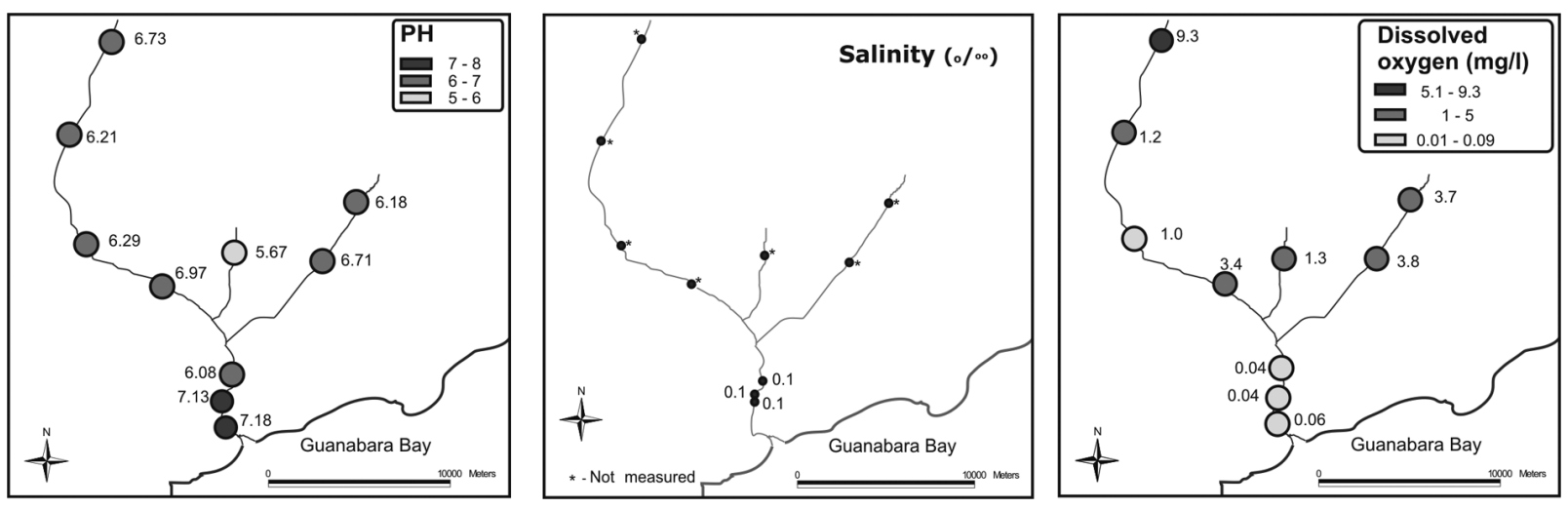

Fig. 3 - Map with the result of the physical-chemical parameters measured in the studied area.

sediments is limited; therefore, the majority of the stations presented lower values, with the exception of station 1, which is located close to the Saracuruna River headwater. This is an uninhabited area with reduced emission of discards in the river system, which constitutes a region that does not experience large proportions of human impacts. The lowest values of dissolved oxygen were detected along the Estrela River stations. It is possible to assume that the lowest concentrations evidenced in this river occur due to the great amount of organic matter in this area. The Estrela River is located in a mangrove area and, due to this factor, it is likely that, in this region, the degradation process of organic matter associated with the bacterial activity is responsible for the intense consumption of this oxygen, practically resulting in the lack of oxygen dissolved in this area (Fig. 3).

\section{PARTICLE SIZE}

The particle size composition of the Estrela River bottom sediments and its affluent ranged from $11 \%$ to $95 \%$ of sand, 4 to $52 \%$ of silt and 1 to $37 \%$ of clay. Through the samples plotted in the Shepard diagram (1945), it can be observed that the sediments of these rivers show a textural heterogeneity and can be grouped into the following classes: sand, silty-sand, sand-siltclay and clay-silt (Fig. 4). The sand and sand-silty classes were prominent; the first one occurred in the five stations and the second type of grain size occurred in three stations along the basin, while the sand-silt-clay and clayed-silt were present in only one station. It is important to stand out that the highest percentages of silt and clay occurred in stations located in the Estrela River and relatively closer to the mouth of the river where the low hydrodynamics energy determines the highest accumulation of fine material. It is possible to observe in the data that the coarse sediment fraction $(>63 \mu \mathrm{m})$ occurs with higher frequency in the majority of the samples in this area. The average levels of silt and clay were $20.3 \%$ and $12.75 \%$ respectively, while the average levels of sand reached $67 \%$. According to Laybauer and Bidone (2001), the reduction of the particle size increases the specific superficial area and the capacity of the cations exchange, as well as the concentration of pollutants in the particle size. So, it is possible to observe that the sediment with particle sizes, which predominate in the area, presents a median that determines the physical-chemical properties and does not help the intense absorption of pollutants.

\section{ORGANIC MATTER}

The organic matter is considered a geochemical carrier of metals in some types of environments due to its capacity of absorbing and complexing metals of both terrestrial and marine origins (Salomons and Förstner 1984, Warren and Haack 2001). The concentration of organic matter found in the studied area showed a great variation among the stations, with a minimum value of $1.31 \%$ in station 1 , located near to the Saracuruna River spring, and the maximum of $16.36 \%$ in station 10, located in the Estrela River. The average levels for all the stations were $5.99 \%$ (Fig. 4). In relation to the organic matter throughout the draining basin, it is possible to observe that the lower concentrations 


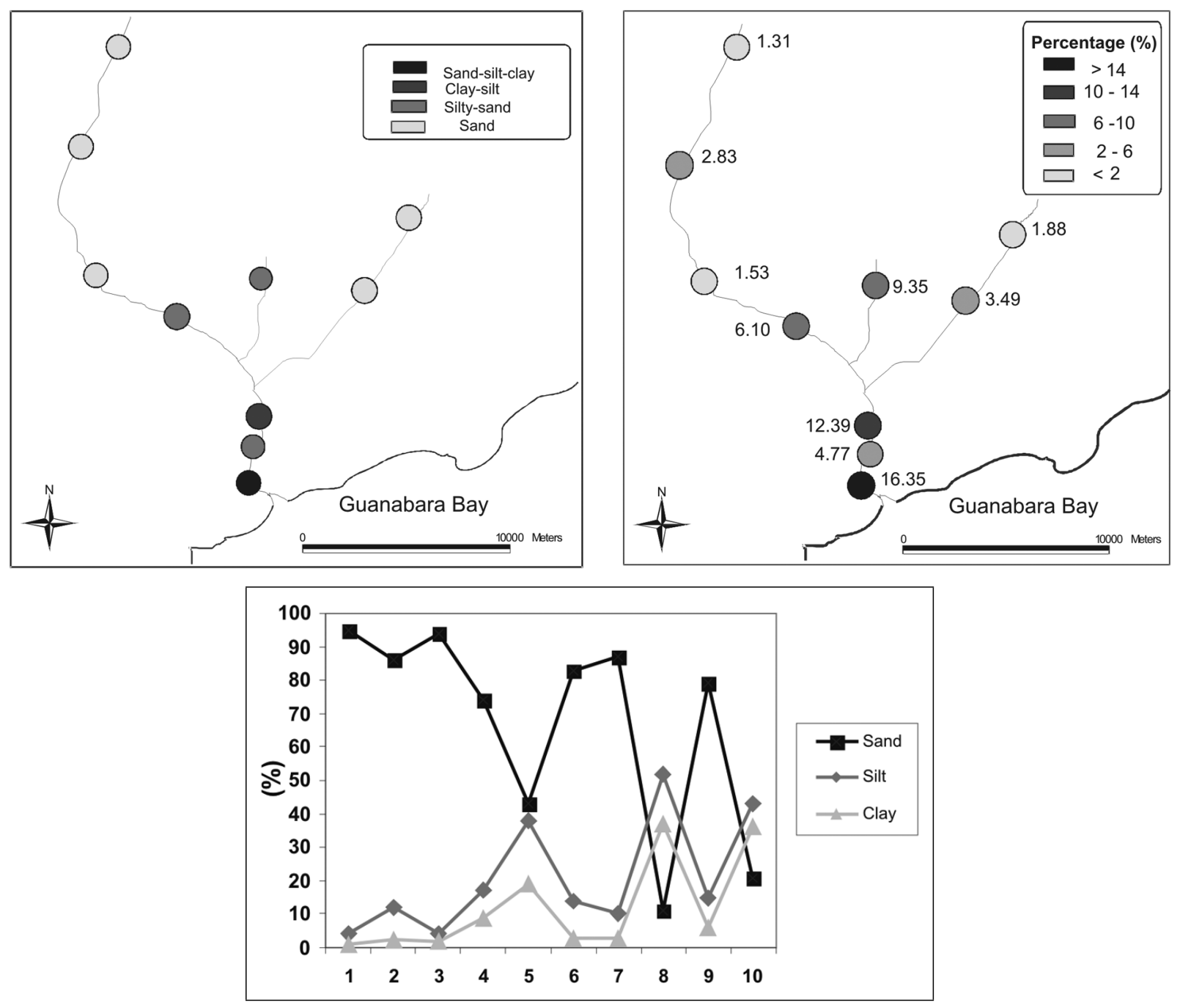

Fig. 4-Map of the particle size distribution of surface sediments and organic carbon content in the studied area.

were found in the Saracuruna River, excepting station 4 , with levels of $6.10 \%$ that are very high considering the other stations in this river. In station 5 , located in the Imbariê River, a relatively high concentration of $9.35 \%$ was found. It is probable that, in this station, the intense input of domestic sewage can contribute to a great amount of organic matter in this area. This river has an open sewage channel due to the great amount of organic matter input in it. Stations 6 and 7, located in the Inhomirim River, show lower concentrations of organic matter, with levels of $3.49 \%$ and $1.88 \%$, respectively, while the stations in the Estrela River show the higher levels, mainly station 10 , which was previously described, and station 8 , with values of $12.39 \%$. The only exception was station 9 , where the detected value was $4.77 \%$. It is important to highlight that the stations with the higher levels of organic matter were also the samples with the higher levels of fine particle sediments, which are associated to areas with lower hydrodynamic energy. Mainly in the stations located in the Estrela River, such as the stations 8 and 10, these areas are characterized by a great input of untreated sewage (Fig. 4).

\section{Total Concentration of Heavy Metals}

The maps of the total heavy metals concentration show a consistent distribution of these elements throughout the Estrela River and its tributaries. These data show a strong correlation with the particle size characteristics 

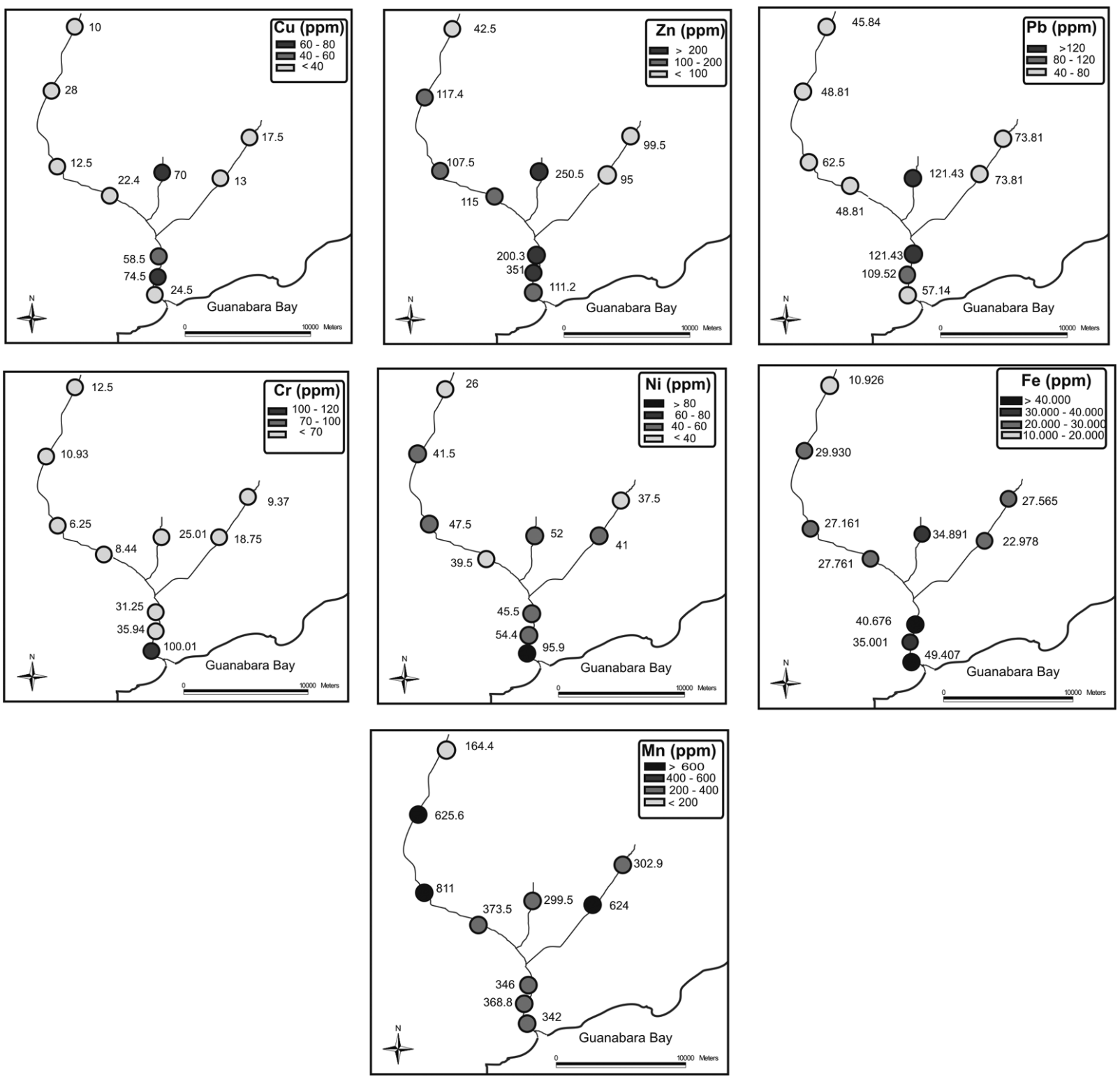

Fig. 5 - Distribution of $\mathrm{Cu}, \mathrm{Zn}, \mathrm{Pb}, \mathrm{Cr}, \mathrm{Ni}, \mathrm{Fe}, \mathrm{Mn}(\mathrm{ppm})$ in the surface sediments of the Estrela River and its main tributaries.

and the concentration of the organic matter in the sediments (Fig. 5). The data indicate that the distributions of the concentrations of the analyzed elements shows a similar standard, in which the highest concentrations were located in the three stations in the Estrela River and in the stations located in the Imbariê Channel. The heavy metals concentration in the superficial sediments of the Estrela River and tributaries showed, in average, low values for all the analyzed elements: $\mathrm{Zn}, \mathrm{Cu}, \mathrm{Pb}$, $\mathrm{Cr}, \mathrm{Ni}, \mathrm{Fe}$ and Mn. However, the data highlight a re- lative enrichment of these elements in some stations. These values were compared with the results obtained in other rivers, with the average shale (Turekian and Wedepohl 1961) and sediments at the base of the sediment cores from Guanabara Bay (Baptista Neto et al. $2000 \mathrm{~b}$ ), in order to estimate the background levels of the heavy metals in this place. Zinc showed an average concentration of $149.05 \mathrm{ppm}$. This value is higher than the average shale and the background value. In small amounts, $\mathrm{Zn}$ is an essential element for the terrestrial 
life, being a structural component in some enzymatic systems (Muniz et al. 2003). The values of concentration of $\mathrm{Zn}$ obtained in this study are very similar to some of works carried out in Guanabara Bay, where high concentrations associated with the discards of domestic and industrial effluents are responsible for the environmental pollution in this estuarine environment (Baptista Neto et al. 2000a, Machado et al. 2001). The maximum value reached by $\mathrm{Cu}$ was of $74.5 \mathrm{ppm}$ in station 9. The majority of the values reached for $\mathrm{Cu}$ throughout the sampling stations was quite similar or below the average shale and the background. $\mathrm{Cu}$, when available in small concentrations, is an essential element in biological processes. However, when the biota is displayed to high concentrations of this element, bioaccumulation can occur with possible toxic effect (Labunska et al. 2000). The average concentration of lead in the studied area was $76.31 \mathrm{ppm}$. This value is very high if compared with the average shale and with the pre-anthropogenic background, which is $20 \mathrm{ppm}$ and $24.4 \mathrm{ppm}$, respectively. According to Abrahim and Parker (2002), almost 95\% of lead that is emitted in the environment is associated with human activities. Chromium presented a great concentration in station 10, which is of $100.01 \mathrm{ppm}$. However, in the other stations, the concentrations were extremely low and the values were lower than the average shale and the anthropogenic background. According to Baptista Neto et al. (1999), one of the main sources of $\mathrm{Cr}$ in urban areas consists of the consuming of mechanical compartments of automobiles. Nickel showed low and homogeneous concentrations throughout the study area, with the exception of station 10, reaching $95.9 \mathrm{ppm}$. The average concentration of nickel was $48.08 \mathrm{ppm}$, which is below the average shale and the pre-anthropogenic background. Through the comparison of the total concentration of the heavy metals found in the studied area with other works carried out in fluvial sediments, such as the study carried out by Souza (1986) in the draining basin of the Estrela River 20 years ago and other rivers that flows to Guanabara Bay, is it possible to observe that the sediments from the Estrela River and tributaries have relatively low concentrations of heavy metals, with the exception of $\mathrm{Pb}$ and $\mathrm{Zn}$ that showed relatively high average values, when compared with other rivers, while
$\mathrm{Cu}$ and $\mathrm{Cr}$ showed lower values (Table I). Elements such as $\mathrm{Pb}$ and $\mathrm{Zn}$ can contaminate the environment through a variety of pollution sources, as the uncontrolled discharge of untreated sewage waste and urban surface runoff (Akcay et al. 2003, Baptista Neto et al. 2000b, Muniz et al. 2003). Unlike the results that were found in this work, Rebello et al. (1986) and Souza (1986) reported high concentrations of $\mathrm{Cu}$ and $\mathrm{Cr}$ at the mouth of the Estrela River, and attributed these high levels of pollution to an intense industrial activity and population growth in this region. It is also important to highlight that, in these previous works, the high levels of these elements in the areas can be explain by the fact that the stations located near the mouth of the river were inserted into the bay and were influenced by hydrodynamic processes typical of estuaries, such as low-energy hydrodynamics, the variation of tides and the accumulation of fine sediments (Perin et al. 1997, Faria and Sanchez 2001), thereby providing high concentrations of these elements in this environment.

\section{CORRELATION COEFFICIENTS}

The degree of correlation between trace metals and other major constituents is often used to indicate the dynamics of the metals. A strong positive correlation of the coefficients of the same metals with the organic matter content of the sediments was found, confirming the ability of the organic matter in the metal complexation (Table II) (Lion et al. 1982, Sanders 1980, Sauvé et al. 2000, Strawn and Sparks 2000). The organic matter also shows a strong correlation with the fine fractions of the sediments (silt and clays) ( $p>0.7)$, which suggests the determinant influence of the local hydrodynamics in some sampling stations. The low circulation allows the accumulation of these fractions, as well as the organic matter conservation through the low dissolved oxygen renew, confirming the inverse relationship of these two parameters $(-0.66)$. This inverse relationship was also reflected in the correlation between the concentrations of heavy metals and the dissolved oxygen, suggesting the oxygen as the main parameter in the heavy metal geochemistry dynamics in this river. Some heavy metals, such as $\mathrm{Pb}, \mathrm{Cu}$ and $\mathrm{Zn}$, also showed a strong correlation among them, which suggests the same source. 


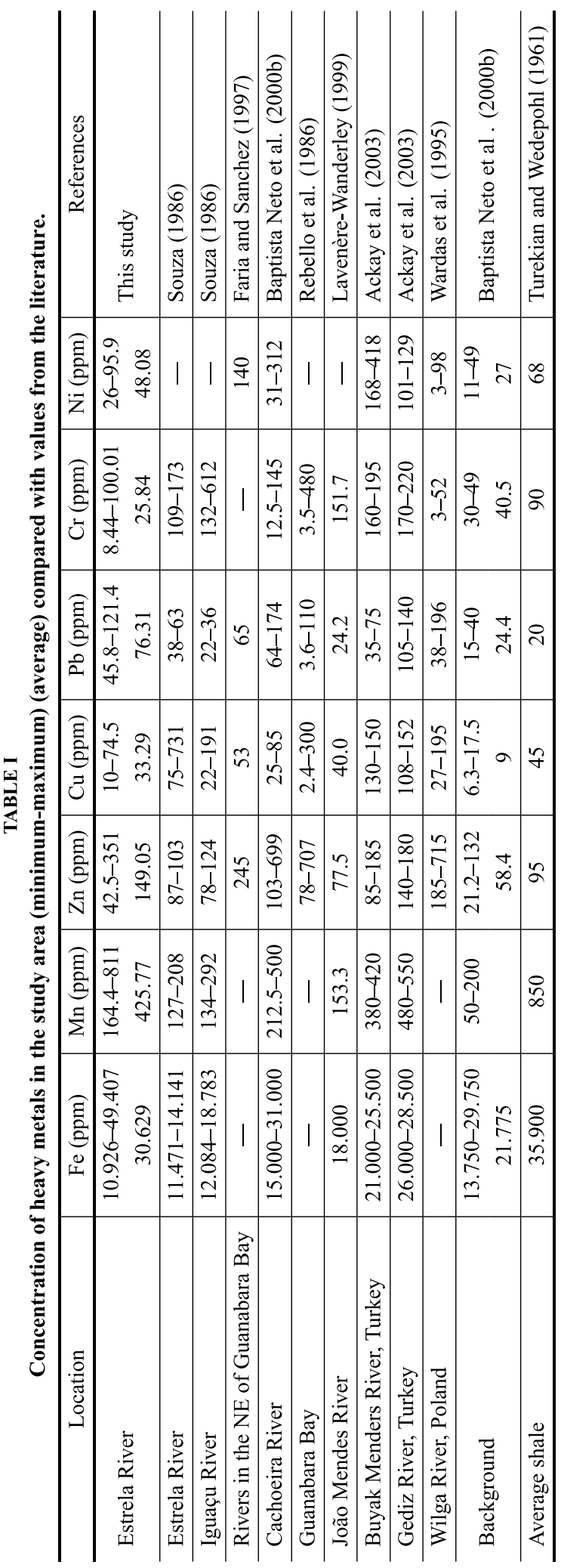

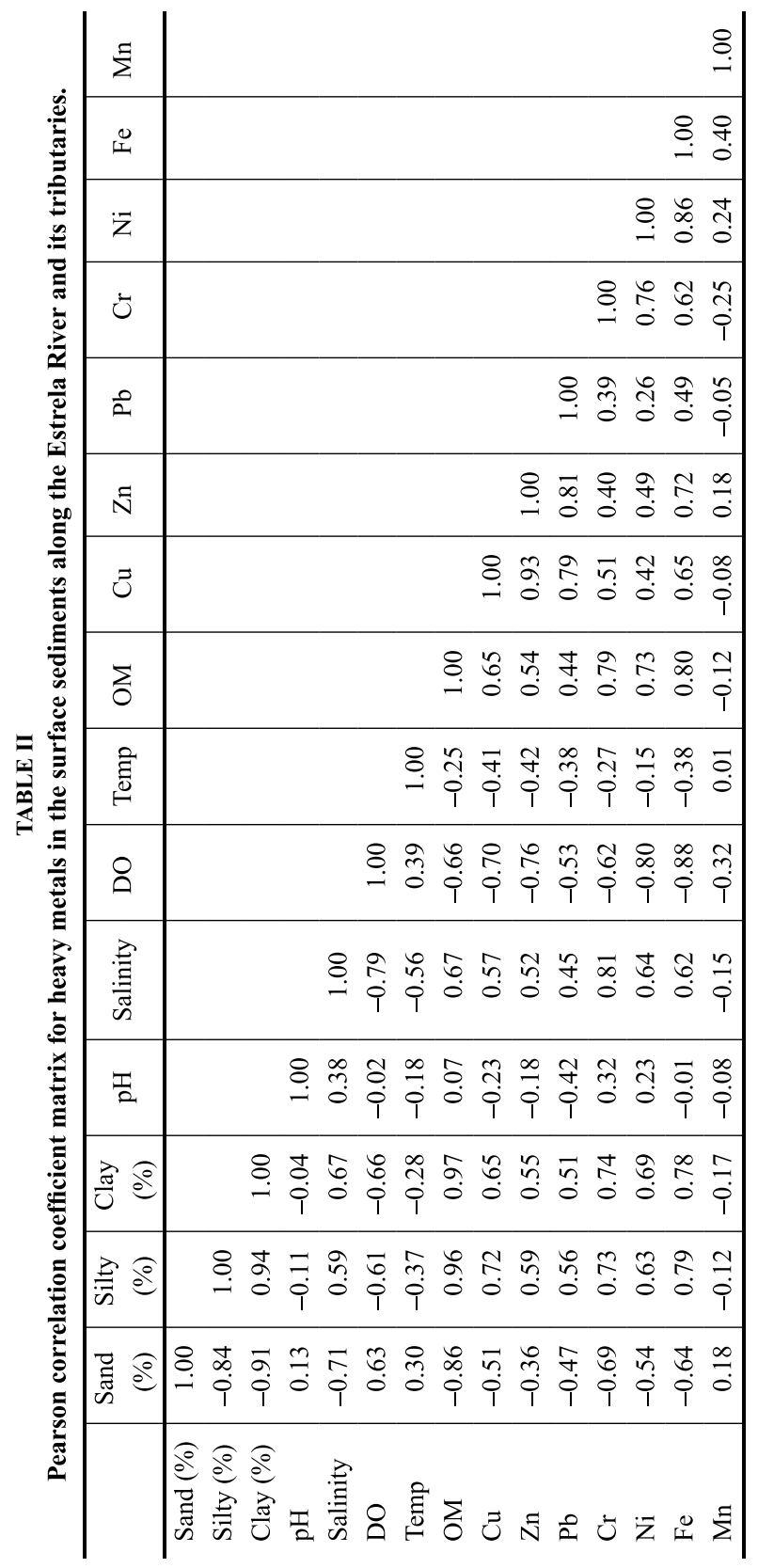




\section{HEAVY METAL PARTITIONING}

\section{COPPER}

The main characteristic observed in the analyzed data was the predominance of $\mathrm{Cu}$ in the reducible phase in the majority of the stations. The carbonatic phase was also prominent in the majority of the samples. The exception of this trend was station 10 , where a great percentage of $\mathrm{Cu}$ was associated with the organic phase followed by the residual phase, reaching values higher than $50 \%$ and $40 \%$, respectively. Despite very low concentrations, the soluble phase occurred in station 4 (Fig. 6). The predominance of the organic phase in station 10 can be attributed to the great concentration of organic matter in this area. The organic matter content detected in station 10 was very high. The partition profiles were very similar to the profile found in the Yamuna River in New Delhi by Jha et al. (1990), where this author observed that copper was mainly associated with the $\mathrm{Fe} / \mathrm{Mn}$ oxyhydroxides phases, differently from some works that reported the intense association of copper with the organic matter in fluvial sediments (KuangChung et al. 2001, ATSDR 1994). However, a previous work carried out in the surface sediments of the Estrela River by Souza (1986) also observed that copper was mainly associated with the organic phase, different from the present work. This factor is due to the kind of sediment found in this work, the majority of coarse sediments and low concentrations of organic matter. According to Pedrozo (2003), the bioavailability of copper decreases with the complexities and absorption of this element to the organic matter and to Fe/Mn oxyhydroxides. Thus, it is deduced that the $\mathrm{Cu}$ detected in the sediments of the Estrela River and its tributaries, complexed with the organic phase and reducted phase, was not bioavailable.

\section{LEAD}

Lead was one of the most stable metals in the sediments, with the highest concentration in the residual phase. In station 3 this phase was the only one found. Despite this factor, a significant contribution of the organic and reductive phases in the sediments was observed, reaching percentages higher than $10 \%$ in the stations 5,8 , 9 and 10. It is important to highlight the presence of the carbonates phase in lower percentages (Fig. 6). According to Lin et al. (1998), the inorganic lead is not available to the environment; therefore, it is on the crystalline matrices of the minerals that constitute the sediments, being thus immovable. Souza (1986) also identified the intense affinity of this element with the residual phase, as reported in this work. Lead associated with the carbonatic and organic phases, even when it is complexed by carbonatic and organic matter, is considered potentially bioavailable, since it can become soluble with changes in the physical-chemical parameters (Gismera et al. 2003, Nowat and Bundy 2001).

\section{Chromium}

Chromium was found mainly associated with the organic, residual and reductivel phases. In stations 1 and 10 the residual phase predominates, which reaches values around $70 \%$ and $60 \%$, respectively. However, in stations 2, 3 and 7, the organic phase occurred in the highest concentrations and reached values higher than $70 \%$ in stations 2 and 3, and the higher percentage of $80 \%$ in station 7 . The carbonatic and soluble phases were absent in all the stations, while the reductivel phase occurred in almost all the analyzed stations, mainly in station 4, where it reached a higher percentage of 90\% (Fig. 6). Souza (1986) demonstrated that $\mathrm{Cr}$ has an intense affinity with the organic phase in the Estrela River sediments. This pattern is similar to the one of this work, which also found an intense association of this element with this chemical phase in the study area. The partition profile recorded in this study was very similar to the data gotten by Baruah et al. (1996) in a work carried out in the Jhangi River sediments, in India, where they also found a strong relationship of chromium with the residual phase. However, in some of the analyzed stations, the organic phase was also very strong, reaching percentages higher than the ones of the residual phase; on the other hand, this pattern is similar to the resulted one observed by Akcay et al. (2003) in the study carried out in the sediments of Gediz and Buyak Menderes Rivers, both located in Turkey.

\section{ZINC}

The largest proportion of zinc was associated with the residual phase. However, the reductive phase was also 

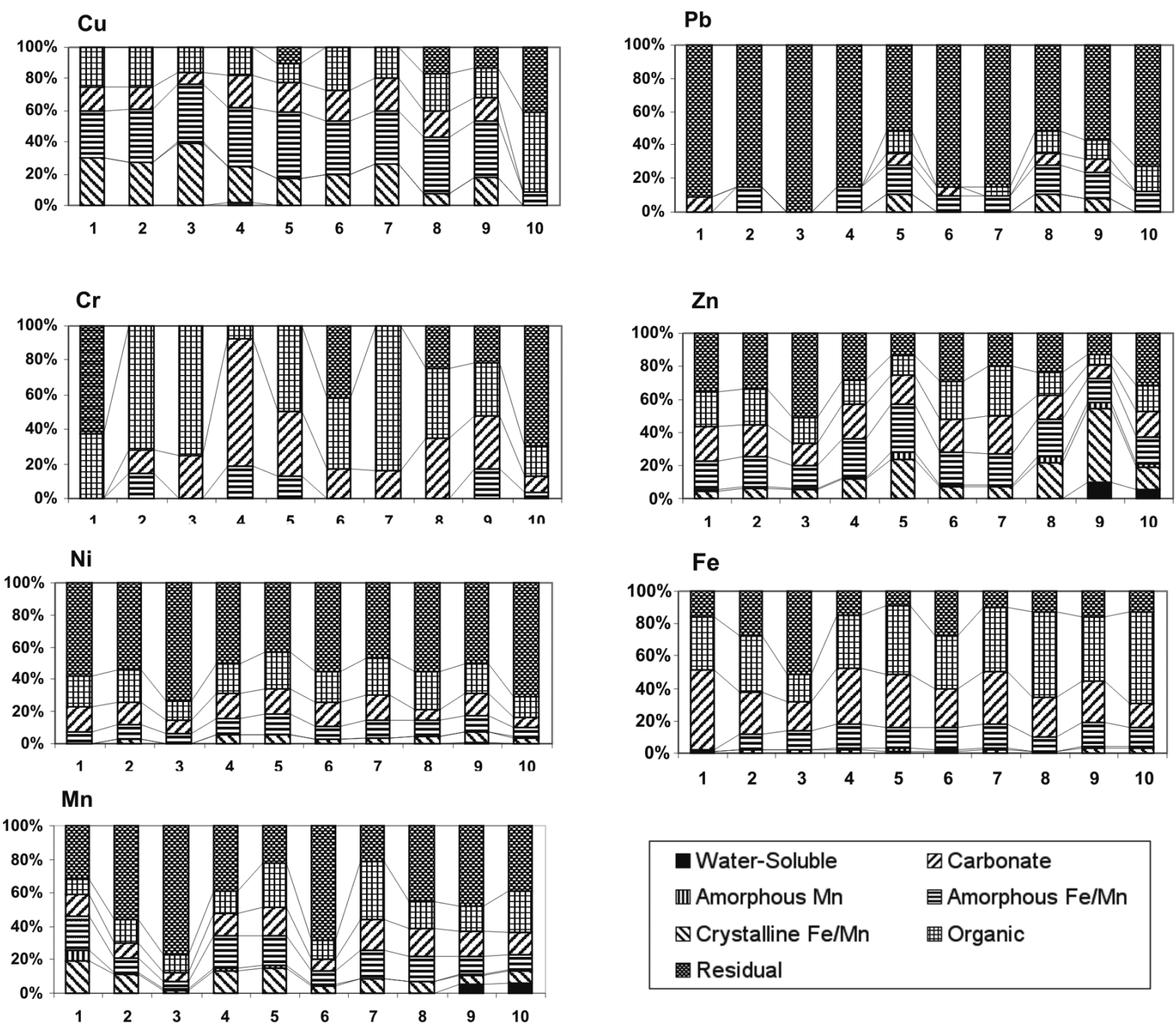

Fig. 6 - Sequential fractionation of heavy metals in the surface sediments of the Estrela River.

present in all the analyzed stations with great percentage in all the stations. The occurrence of this metal in the soluble phase was also detected only in stations 9 and 10 , with a concentration around $10 \%$. The carbonatic phase occurred in all the stations, reaching the highest value in station 9, where it reaches more than $40 \%$. The organic phase occurred in all the stations, with the highest percentage of $20 \%$ in some of the stations (Fig. 6). In the work carried out by Souza (1986), this metal shows a very mobile characteristic, since it is distributed in almost all the chemical phases in the sediments, mainly in the residual phase. In the present study, $\mathrm{Zn}$ also occurred in all the phases. However, the reductivel phase occurred in a great proportion in almost all the analyzed stations. In the study carried out by Zhang and Guijiu (1995) in the Kangjiaxi River sediments, in China, the soluble phase of Zinc was detected, which reached a percentage of $1.5 \%$. This value was lower than the detected one in some of the places of the drainage basin in this study, as previously described.

NICKEL

The partition of nickel occurred significantly between the residual and organic phases. However, the highest concentrations occurred in the residual phase in all the analyzed stations. The organic phase occurred in all the sampling stations, reaching values around $20 \%$. The soluble phase occurred in stations 9 and 10. However, in very low concentrations (Fig. 6), Akcay et al. (2003) demonstrated the predominance of $\mathrm{Ni}$ associated with 
the residual phase in fluvial sediments, while Baruah et al. (1996) detected the affinity of this metal with the reducible phase. According to Muniz et al. (2003), sulfate of iron and iron and manganese minerals are the main natural sources of $\mathrm{Ni}$ for the environment. In the rivers, nickel is transported as part of the precipitated particles with the organic matter (ACGIH 2001), being able to become bioavailable in case of changes in the physical-chemical parameters. The decreases in $\mathrm{pH}$ generally mobilize Ni. Most nickel compounds is relatively soluble in $\mathrm{pH}$ lower than 6.5. However, $\mathrm{Ni}$ occurs predominantly in the insoluble form, as hydroxide of nickel, in pH lower than 6.7 (ACGIH 2001).

\section{IRON}

Iron occurred in all the phases, except in the soluble phase. A very similar pattern occurred among the organic, reductive and residual phases. The organic phase was the predominant one, mainly in station 10 , while the residual phase showed to be more expressive and occurred in higher proportions in station 3, reaching values around $60 \%$ to $50 \%$, respectively. One small percentage of this element was detected associated with the carbonatic phase in all the sampling sites (Fig. 6). Souza (1986) reported the intense affinity of iron with the residual phase in all the samples analyzed in her work, which is different from the present work. In this study it occurred mainly associated with the organic phase, except in station 3. Zhang and Guijiu (1995) also highlighted the predominance of iron in more stable chemical phases, such as the organic, reducible and residual phases, which are similar to the associated phases of $\mathrm{Fe}$ observed in the Estrela River. Iron in the sediments occur complexed, mainly with the humic substances that contain metallic carboxylic and phenol functional groups, being capable of reducing ions and then increasing their solubility and availabity. Thus, it is evident that iron associated with the organic phase can become bioavailable in case of physical-chemical variations in the environment (Lu et al. 2000).

\section{MANGANESE}

Mn was associated to the residual phase in all the stations, mainly in stations 3 and 6 , reaching values higher than $60 \%$. A significant alternation between the organic and reductive phases also occurred, while the carbonatic phase occurred in the speciation of $\mathrm{Mn}$ in less proportion, except in station 1, which showed a percentage of almost $20 \%$. Great parts of manganese occur in the residual phase, followed by the organic and reductivel phases. Thus, through the fractioning of the metal, it is visible that the most concentration of $\mathrm{Mn}$ is unavailable, since it is in the residual phase and part of it in the potentially bioavailable phase, and since the physical-chemical changes can increase its solubility. The soluble phase also occurs in stations 9 and 10 , though in very low concentrations (Fig. 6). Souza (1986) also detected the preeminence of the residual phase and the significant presence of the organic and reductivel phases in her work. This author also reported the existence of the carbonatic phase in the metal fractioning, though in lower concentrations than the ones of other phases. Akcay et al. (2003) reported that Mn is poorly absorbed by organic matter. Thus, the author suggested that the bioavailability of $\mathrm{Mn}$ in organic matter of sediments is lower, and, in this way, an environment submitted to intense industrial and agricultural activities can deliver higher concentrations of $\mathrm{Mn}$ in the exchangeable phase.

\section{CONCLUSIONS}

By the study carried out in the Estrela River about the concentration of heavy metals in the bottom sediments, it is possible to conclude that the sediments are slightly contaminated with the metals when compared with the background values mentioned in this work. However, the concentrations of heavy metals are lower than the ones in other rivers that also flow into Guanabara Bay. It is important to highlight that the levels of organic matter and the particle size characteristics of the bottom sediments of the Estrela River were not propitious for the accumulation of metals because of the predominant particle sizes, mainly sands. Through the process of partitioning the heavy metals, it was possible to observe the prominence of the residual and the reductivel phases in the complexation processes of these elements. However, the affinity of these elements with the organic phase was also registered. In such a way, great part of the analyzed metals can be considered as unavailable 
for this environment, not representing great environmental risks even if the elements that were associated with the organic phase are potentially bioavailable. Therefore, changeable physical-chemical conditions can increase the solubilization and then allow the bioavailability of the contaminants for the ecosystem. This paper shows the necessity to carry out continuous surveys throughout the draining basin in order to assess the possible sources of pollutions to the river, and also the possible changes in the amount of pollutants throughout the year.

\section{ACKNOWLEDGMENTS}

Funding for this project was provided by Agência Nacional do Petróleo (ANP) through a scholarship, and a research grant from Conselho Nacional de Desenvolvimento Científico e Tecnológico (CNPq). The writers are also indebted to The School of Geography - Queen's University for the analyses of this work. J.A. Baptista Neto is a Researcher from Conselho Nacional de Desenvolvimento Científico e Tecnológico (CNPq).

\section{RESUMO}

Neste estudo, analises geoquímicas de dez amostras de sedimentos coletadas ao longo do sistema fluvial do rio Estrela, que deságua na porção norte da Baía de Guanabara, evidenciam a presença de impactos antropogênicos nesta área. As concentrações de $\mathrm{Fe}, \mathrm{Mn}, \mathrm{Zn}, \mathrm{Cu}, \mathrm{Pb}, \mathrm{Cr}$ e $\mathrm{Ni}$ obtidas foram ligeiramente elevadas, quando comparados com valores encontrados em ambientes naturais. A granulometria e o teor de matéria orgânica na maioria dos pontos analisados mostraram características não favoráveis à acumulação destes poluentes devido à baixa concentração de matéria orgânica e à forte presença de fração areia. Realizou-se também o fracionamento dos metais pesados nos sedimentos e constatou-se a preeminência da fase residual e redutível, além da ocorrência significativa da fração orgânica em alguns pontos analisados. Estes fatores evidenciam, portanto, riscos potenciais de contaminação, onde os metais associados à fase orgânica podem se tornar biodisponíveis em processos de solubilização, proporcionados por mudanças físico-químicas que podem ocorrer neste ambiente aquático.

Palavras-chave: Rio Estrela, Baía de Guanabara, metais pesados, fracionamento.

\section{REFERENCES}

Abrahim G And PARKer R. 2002. Heavy-metal contaminants in Tamaki Estuary: Impact of city development andgrowth, Auckland, New Zealand. Environ Geol 42: 883-890.

ACGIH - AMERICAN CONFERENCE OF GOVERNMENTAL Industrial Hygienists. 2001. Threshold limits values and biological indices for 2001. Cincinatti, p. 27-39.

AkCay H, Orguz A And Karapire C. 2003. Study of heavy metal pollution and speciation in Buyak Menderes and Gediz river sediments. Water Res 37: 813-822.

AMADOR ES. 1997. Baía de Guanabara e ecossistemas periféricos - Homem e Natureza: Edição do autor, Rio de Janeiro, RJ, Brasil, 539 p.

ATSDR-AgEnCy For TOXIC SubStAnCES AND DiseASE REgistry. 1994. Toxicological Profile for zinc. Atlanta, USA, $243 \mathrm{p}$.

Baptista Neto JA, Gingele FX, Leipe T And Brehme I. 2006. Spatial Distribution of Heavy metals in Surficial Sediments from Guanabara Bay: Rio de Janeiro, Brazil. Environ Geol 49: 1051-1063.

Baptista Neto JA, Smith BJ And McAllister JJ. 1999. Concentrações de metais pesados em sedimentos de escoamento superficial urbano: Implicações quanto à qualidade ambiental de Niterói, RJ, Brasil. An Acad Bras Cienc 4: 981-995.

Baptista Neto JA, Smith BJ and McAllister JJ. 2000a. Concentrações de metais pesados em sedimentos de escoamento superficial urbano: Implicações quanto à qualidade ambiental de Niterói, RJ, Brasil. An Acad Bras Cienc 4: 981-995.

Baptista Neto JA, Smith BJ And McAllister JJ. 2000b. Heavy metal concentrations in surface sediments in a nearshore environment, Jurujuba Sound, SE, Brazil. Environ Pollut 109: 1-9.

BARUAH NK, KOTOKY P, BHATTACHARYyA KG AND Borah GC. 1996. Metal Speciation in Jhanji River Sediments. The Science of the Total Environ 193: 1-12.

BuUrman P, VAn Lagen B And Velthorst EJ (Eds). 1996. Water soluble salts. Manual for Soil and Water Analysis. Backhuys Publishers: Leiden, 312 p.

Campbell PGC and Tessier A. 1989. Geochemistry and bioavailability of trace metals in sediments. In: BOUDOU A AND Ribeyre F (Eds), Aquatic Ecotoxicology: Fundamentals concepts and methodologies. CRC press, Boca Raton, p. 125-148. 
CARreira RS, Rebello AHL, REAdman JWF, Tim W, Macko SA AND VeIgA A. 2002. Changes in the sedimentary organic carbon pool of a fertilized tropical estuary, Guanabara Bay, Brazil: an elemental, isotopic and molecular marker approach. Mar Chem 79: 207-227.

EsteVEs FA. 1998. Fundamentos de Limnologia. Interciência, Rio de Janeiro, Brasil, 602 p.

FARIA MM AND SANCHEZ B. 2001. Geochemestry and mineralogy of recent sediments of Guanabara Bay (NE sector) and its major rivers - Rio de Janeiro State Brazil. An Acad Bras Cienc 73: 121-133.

FEEMA - FundaÇão Estadual DE Engenharia do Meio Ambiente. 1990. Projeto de recuperação gradual do ecossistema da Baía de Guanabara. Indicadores ambientais de degradação. Obras e projetos de recuperação, Rio de Janeiro, Brasil, 365 p.

FEEMA - FundaÇão Estadual DE ENGENharia do Meio Ambiente. 1998. Qualidade da água da Baía de Guanabara - 1990-1997. Secretaria do Estado do Meio Ambiente, Rio de Janeiro, Brasil, 180 p.

Gismera MJ, Lacal J, Silva P, Garcia R, Sevilha MT AND PROCÓPIO JR. 2003. Study of metal fractionation in river sediments. A comparasion between kinetic and sequential extraction procedures. Environ pollut 127: 175-182.

JHA PK, Subramaninan V, Sitawasd R AND VAN GRIEKEN R. 1990. Heavy metal in sediments of the Yamuna River (A tributary of the Ganges). India. Sci Total Environ 95: 7-27.

KJerve B, Ribeiro CHA, DiAs GTM, Filipo AM AND QUARESMA VS. 1997. Oceanografic characteristics of an impacted coastal bay: Baía de Guanabara, Rio de Janeiro, Brazil. Cont Shelf Rese 17: 1609-1643.

KuAng-Chung Y, Li-Jyur T, SHIH-Hsiung C AND SHIEN-TSONG H. 2001. Chemical binding of heavy metals in anoxic river sediments. Water Res 35: 40864094.

Labunska I, Stringer R And Brigden K. 2000. Poluição por metais pesados e compostos orgânicos associada à unidade da Bayer em Belford Roxo, Rio de Janeiro. Laboratórios de Pesquisa do Greenpeace, Departamento de Ciências Biológicas, Universidade de Exeter, Reino Unido, $67 \mathrm{p}$.

LAVÈnERE-WANDERLEY AAO. 1999. Caracterização ambiental da Lagoa de Itaipú através do entendimento dos processos sedimentares em associação com a dinâmica atual. Dissertação de Mestrado. Universidade Federal Fluminense, 141 p. (Unpublished).
LAYBAUER L AND BIDONE ED. 2001. Caracterização textural dos sedimentos de fundo do Lago Guaíba (Sul do Brasil) e sua importância em diagnósticos ambientais. Instituto de Geociências. Universidade Federal do Rio Grande do Sul, p. 13-26.

Lin Z, Harsbo K, Ahlgren M and Qvafort U. 1998. The source and fate of $\mathrm{Pb}$ in contaminated soil at the urban area of Falun in Central Sweden. Sci Total Environ 209: 47-58.

Lion LW, Altmann RS And Leckie JO. 1982. Trace metal adsorption characteristicsof estuarine particulate matter: evaluation of contributions of $\mathrm{Fe} / \mathrm{Mn}$ oxide and organic surface coatings. Environ Sci Technol 16: 660666.

LU XQ, Hanna JV AND John WD. 2000. Source indicators of humic substances: An elemental composition, solid state $13 \mathrm{C} \mathrm{CP/MAS} \mathrm{NMR} \mathrm{and} \mathrm{Py-} \mathrm{GC/MS} \mathrm{study.}$ Appl Geochem 15: 1019-1033.

Machado W, Moscatelli M, Resende LG And LACERDA LD. 2001. Mercury, zinc and cooper accumulation in mangrove sediments surrounding a large landfill in southeast Brazil, Environ Pollut 120: 455-461.

Muniz P, Danulat E, Yannicelli B, Garcia-Alonso J, Medina G And Bicego MC. 2003. Assesment of contamination by heavy metals and petroleum hydrocarbons in sediments of Montevideo harbour (Uruguay). Environ Int 1096: 1-10.

Noronha AR. 1998. A Bacia do Rio Estrela: Subsídios ao Monitoramento Ambiental da Baía de Guanabara. Dissertação de Mestrado. Universidade Federal do Rio de Janeiro, 119 p. (Unpublished).

NowAT FS AND BUNDY KJ. 2001. Correlation of fieldmeasured toxicity with chemical concentration and pollutant availability. Environ Int 27: 479-489.

Pagnanelli F, Mosca E, Giuliano V and Toro L. 2004. Sequential extraction of heavy metals in river sediments of an abandoned pyrite mining area; pollution detection and affinity series. Environ Pollut 132: 189-201.

Pedrozo MFM. 2003. Cobre. In: De Azevedo FA, Metais-Gerenciamento da Toxicidade. Ed. Altheneu, São Paulo, Brasil, p. 143-184.

Perin G, Fabris R, Manete S, Wagener AR, HamaCHER C AND SCOTTO S. 1997. A five year study on the heavy-metal pollution of Guanabara bay sediments (Rio de Janeiro, Brazil) and evaluation of the metal bioavailability by means of speciation Wat Res 31: 3017-3028. 
Rebello AL, HaEkel W, Moreira I, SANTElli R AND Schroder F. 1986. The Fate of Heavy Metals in an Estuarine Tropical System. Elsevier Science Mar Chem 18: $215-225$.

SAlOMONS W AND FÖRSTNER U. 1984. Metals in the Hydroclycle. Berlin: Springer Verlag, 349 p.

SANDERS JR. 1980. The use of adsorption equations to describe copper complexingby humified organic matter. J Soil Sci 31: 633-641.

Sauvé S, Hendershot W And Allen HE. 2000. Solidsolution partitioning of metals in contaminated soils: dependence on $\mathrm{pH}$, total metal burden, and organic matter. Environ Sci Technol 34: 1125-1131.

SHEPARD FP. 1954. Nomenclature based on sand-silty-clayratios. J Sediment Petrol 24: 151-158.

SouZA MM. 1986. Estudo comparativo da distribuição geoquímica de metais pesados entre duas áreas contaminadas e uma não contaminada, no litoral Sul do Rio de Janeiro. Dissertação de Mestrado. Universidade Federal Fluminense, 60 p. (Unpublished).
STRAWN DG AND SPARKS DL. 2000. Effects of soil organic matter on the kinetics andmechanisms of $\mathrm{Pb}(\mathrm{II})$ sorption and desorption in soil. Soil Sci Soc Am J 64: 144-156.

TUREKIAN KK AND WEDEPOHL KH. 1961. Distribution of elements in some major units of the earth's crusts. Geol Soc of Am Bulletin 72: 175-192.

WARDAS M, BUDEK L AND RYBICKA EH. 1995. Variability of heavy metals content in bottom sediments of the Wilga River, a tributary of the Vistula River (Kraków area, Poland). Appl Geochem 11: 197-202.

WARREN LA AND HAACK EA. 2001. Biogeochemical controls on metal behaviour in freshwater environments, Earth-Science Reviews 54: 261-320.

ZHANG L AND GUIJIU Z. 1995. The species and geochemical characteristics of heavy metals in the sediments of Kangjiaxi River in the Shuikoushan Mine Area, China Appl Geochem 11: 217-222. 